\title{
Yoga Research - Some Reflections
}

\author{
Mukund Vinayak Bhole* \\ Consultant in Yoga Therapy, Lokmanya Medical Research Centre, India
}

Submission: September 29,2018; Published: March 19, 2019

*Corresponding author: Mukund Vinayak Bhole, Consultant in Yoga Therapy, Lokmanya Medical Research Centre, India.

\begin{abstract}
Even though various research studies related with Yoga are important in their own way, serious yoga aspirants some knowledge of medical research can feel that the work of fundamental nature (Phase-I) is lacking and it needs to be given its proper place before undertaking studies in relation to the clinical and other types of applications indicating Phase III and IV studies. It may turn out that these studies are based on weak foundations of traditional Yogic concepts and doctrines based on experiencing the person by the person rather than making objective observations. Usually, the control group is not given a comparable 'intervention' of 'non-yogic type'. In medical studies, placebo resembles the intervention without the active principle. 'No activity' cannot be treated as 'placebo' for 'Yoga Intervention'.
\end{abstract}

Keywords: Yoga research; Yoga education; Asana; Pranayama; Vayu; Prana.

\section{Introduction}

The historical Chicago Lecture by Swami Vivekananda in 1893 [1] aroused the interest of the western world to study and practice 'Yoga'. It was followed by the curiosity to understand the working of 'Yoga' by subjecting it to the modern laboratory investigations. The earliest studies dating back to 1920-21 and for some decades thereafter were of physiological nature. It was followed by psychological studies and studies related with the human consciousness and behavior [2,3]. By the passage of time, 'Yoga' has found its way in various aspects and walks of human life in its original form or modified forms to suit the needs and demands of the human society. Interested people and Institutions in different countries are undertaking research studies to ascertain the efficacy and authenticity of traditional [4] as well as contemporary modern 'Yoga' [5,6]. Research articles related with 'Yoga' published in various peer reviewed indexed journals (including JYP) revealed following information which was felt worth sharing with the scientific community, Yoga teachers/ educators/therapists and Yoga students/practitioners.

\section{Observations Worth Sharing}

People and Institutions interested and involved in subjecting 'Yoga' to laboratory investigations can be grouped under different categories as follows:

a) Physical educationists and sports people having major interest in understanding the effect of 'Yoga' on various parameters of physical fitness useful for competitive games and sports of different kinds.

b) Medical and Para-medical professionals interested in the application of 'Yoga' in different clinical conditions with. c) Health, Fitness and Wellness professionals with the interest in maintaining health, general fitness and work efficiency.

d) Yoga practitioners (sadhanas) and Yoga Teachers wanting to know and understand the 'modus operandi' and the outcome of traditionally taught and followed Yoga practices as a spiritual discipline (Yoga Sadhana).

e) Yoga enthusiasts teaching, learning and practicing Yoga out of interest and curiosity in a mechanical way.

f) Preparing for Yoga Competitions and Demonstrations involving potential risk of sustaining serious overt and covert traumas and injuries.

It is observed that different 'yoga protocols', mostly comprising of

a) Body positions (Asanas),

b) Breathing practices (Pranayama),

c) Concentration practices (Meditation or Dhyana), sometimes

d) 'Mantra recitation'

e) Special yoga techniques (Kriyas, Mudras and 'Bandhas)

Are given as 'yoga intervention' to the experimental group to study its effect on selected parameters of physical, physiological and psychological nature. Very seldom it assumes spiritual dimension. Standardized techniques/practices with proper nomenclature is expected to be used for research and training. However, it is often noticed that many research works are lacking 
in these important details after perusing the methods described in the texts and making observations by attending the actual yoga classes run by the Yoga teachers. Some examples are given below:

\section{'ĀSANA' as 'Exercise'}

Usually 'asanas' are described and taught as 'physical exercises. According to the Yoga-sutras of Patanjali [7], 'Posture' or 'Postural patterns' and 'Postural substrate' would be the most appropriate psycho-physiological understanding of 'asanas. On analysis, Psycho-physiology of 'Exercises' and 'Exercise routines' is different from the psycho-physiology of 'Postures' or 'Postural patterns' and 'Postural substrate'. In Sanskrit language, 'Vyāyāma' is the nearest equivalent for 'Exercise'. The other terms used for 'asanas' are 'Poses' and 'Positions'. 'Mudra' and 'Pavitra' are the Sanskrit terms for these words. 'Pavitra' implies assuming suitable body position to release some sort of action in the external world such as lifting weight, start running, boxing, etc. while 'Mudra' (pose) denotes the expression of some mood or emotion. The brain areas involved in these activities and actions will be different than those involved in maintaining a 'posture' or 'postural pattern' (asanas).

\section{'Prānayama' as 'Voluntary Breathing Exercise'}

Usually, 'Pranayama' is described as 'voluntary breathing exercise' [8]. Etymologically, pranayama is understood as 'Prana + Āyāma' which means extension or expansion of 'Prāna' [9]. According to the traditional texts, 'Hathapradipikā' [10] \& SiddhaSiddhant Paddhati [11], one is expected to be working with the 'prana Vayu' and 'Apana Vayu' residing inside the body and involved with breathing and the movement of breath. These and other traditional Yogic texts refer to 'ten vayus', 'five main vayus' useful for 'Yoga Sadhana' and 'five secondary vayus' indicating disturbed state of being/consciousness.

a) Authors of the modern Yoga texts are seen to refer to 'Prana Vayu' as Oxygen and 'Apana Vayu' as Carbon-di-oxide. Many times, yoga teaching is based on the assumption that 'Prana' and 'Prana Vayu' as Oxygen $[12,13]$. The term 'Vayu' appearing in traditional Yoga literature dates back to 300 to 500 BCE. It is related with life while chemical gases such as 02 -CO2 owe their discovery to Alchemy [14]. Therefore, vayus of yoga cannot be equated and/or compared with the chemical gases. It will be realized that studies based on gaseous exchange will not do proper justice to the studies related to Pranayama mentioned in Yoga even though these studies are important for the scientific community and the common man.

b) Very often, the terms 'Vayu', 'Prana' and 'Svasa' are interchanged and used indiscriminately by translators in English without giving any logic and reasoning for doing so [10]. Present author strongly feels that vayus represent neuro-muscular activities and/or psycho-neuro-muscular actions. 'Prana' represents 'Sensory activity' contributing to awareness or consciousness and 'svasa' represents the flow of breath. It is possible to sense, monitor and modify the 'flow of breath' (svasa-prasvasa in yoga) as well as neuro-muscular activities and actions with reference to breathing (Mechanics of breathing). However, it may not be easy to perceive, monitor and modify gaseous exchange and various parameters used in laboratory studies in relation to respiration.

\section{'Meditation' (Dhyana) as 'Concentration'}

Concentration implies voluntary motor activity while 'Dhyana' represents 'sensory activity' leading to a state of consciousness or awareness [7].

\section{Conclusion}

Even though various research studies related with Yoga are important in their own ways, serious yoga aspirants and medical scientists can feel that the work of fundamental nature (Phase-I) is lacking and needs to be given its proper place before undertaking studies in relation to the applied aspects indicating Phase III and IV. It may turn out that these studies are based on weak foundations of traditional Yogic concepts and doctrines. Usually, the control group is not given a comparable 'non-yogic protocol' of any kind. In medical studies, placebo resembles the intervention without active principle. 'No activity' cannot be treated as 'placebo' for 'Yoga Intervention'.

\section{References}

1. Swami Vivekananda (1893) at the Parliament of the World's Religions.

2. Wenger MA, Bagchi BK (1961) Studies of autonomic functions in practitioners of yoga in India. Journal of general systems Research 6(4): 312-323

3. Yoga and Consciousness Studies: Biofeedback Research and Yoga.

4. The 7 True Traditional Types of Yoga.

5. 14 different types of yoga and their benefits you must know.

6. Types of Yoga, Modern Forms of Yoga, Ancient Forms of Yoga.

7. The Yoga Sutras of Patanjali (Sadhana pada: Sutra 46).

8. Pranayama (Breathing) Exercises \& Poses. Yoga Journal.

9. Pranayama.

10. (1998) Hathapradipika of Svatmaram Critical edition published by Kaivalyadhama Yoga Institute, Lonavala, India, (Chapter-II specially Verses $2 \& 3$ )

11. (2005) Siddha-siddhanta-paddhati by Goraksanath. Critical edition published by Lonavala Yoga Institute, Lonavala, India, (Chapter-I, Verses 40 \& 67).

12. Is prana a food and oxygen? - General Yoga -SS Yoga Forums.

13. What is the difference between oxygen and prana? Are they the same ...?

14. Google Wikipedia $\mathrm{CO}_{2}$ gas was discovered around 1640 , Nitrogen gas (azote) around 1772, Oxygen gas around 1773-74 and Chlorine gas around 1774). 
This work is licensed under Creative Commons Attribution 4.0 License

DOI: 10.19080/JYP.2019.07.555701

Your next submission with Juniper Publishers
will reach you the below assets
- Quality Editorial service
- Swift Peer Review
- Reprints availability
- E-prints Service
- Manuscript Podcast for convenient understanding
- Global attainment for your research
- Manuscript accessibility in different formats
( Pdf, E-pub, Full Text, Audio)
- Unceasing customer service
Track the below URL for one-step submission
https://juniperpublishers.com/online-submission.php

